\title{
Service Quality Models: A Gap Study
}

\author{
Kiran \\ Research Scholar, CRSU, Jind, Haryana, India \\ E-mail: malik.kitty@gmail.com
}

Dr. Ajmer Singh

Faculty, Department of Management, Crsu, Jind, Haryana, India

E-mail: singhajmer@rediffmail.com

Received: May 11, 2016 Accepted: May 22, 2016

doi:10.5296/ber.v6i1.9636 URL: http://dx.doi.org/10.5296/ber.v6i1.9636

\begin{abstract}
During the past three-four decades, service quality becomes an important area for research. This paper makes an attempt to study different service quality models given by the key contributors in this area. The paper examines different models of service quality on the basis of the review of the literature. The models that have been analyzed in this paper are-Gronroos Model, Lehtinen and Lehtinen three-dimensional model, PZB Gap Model, three components Model, RSQS Model and Brady and Cronin Hierarchical model. From the review of the above models, we find out that there is a lot of work still available which can be done to fill the gap. Hence, this paper will provide an opportunity to the researcher to do research in those areas which are still left to be covered.
\end{abstract}

Keywords: Service Quality, Service Quality Models, PZB Gap Model, RSQS Model

\section{Introduction}

The retail industry is the biggest private sector industry in the world economy and India is anticipated as the most significant place for retail investors. India is the fifth leading place for retail in the world. In India, the participation of retail industry is over 10 percent in country's Gross Domestic Product (GDP) and it is contributed around 8 percent in the country's total employment. (Media Reports, Press Releases, DIPP Publication, Press Information Bureau, India Budget 2015-16). The retail market in India is expected to reach US \$ 1.3 trillion by 2020 from US $\$ 600$ billion in 2015. (BCG and RAI report "Retail 2020: Retrospect, Reinvent, Rewrite"). The key drivers in Indian retail industry are income expansion, nuclearization, urbanization and attitudinal shifts. The report states that the overall Indian retail market is expected to reach at 
12 percent per annum, the Indian modern trade would expand twice as fast at 20 percent per annum and Indian traditional trade would expand at 10 percent per annum.

Indian Fast Moving Consumer goods (FMCG) market expected to boost up to US \$ 103.7 billion by 2020 from US $\$ 47.3$ billion in 2015. An Indian online retail profit is estimated to grow to US $\$ 70$ billion by 2020 from US $\$ 6$ billion in 2015. (indiaretailing.com, Tech Sci Research).Direct selling industry in India is increased 6.5 percent in FY 2014-15 to Rs. 7,958 crores (US \$ 1.19 billion) and it is expected to reach at Rs. 23,654 crores

(US \$ 355 billion) by FY 2019-20.( India Direct Selling Association and PHD). India position eleventh after United States, China, Canada, UK, Brazil, Germany, Austria and Mexico in market potential. India has taken this position in global retail ranking due to the high market potential, low economic risk, and moderate political risk. In net retail sales, India is ranked third after China and Brazil. ( AT Kearney 2015, Tech Sci Analysis)

\subsection{Evolution of Indian Retail}

The Indian retail industry development can be divided into four phases:

- Initiation - Pre-1990s

- Conceptualization - 1990 to 2005

- Retail Expansion - 2005 to 2010

- Consolidation and Growth - 2010 onwards

1. Retail Initiation: In the initiation phase, manufacturers opened their own outlets. This phase was conquered by manufacturers. The Raymond Group, Bombay Dyeing and Bata were names of retail instigation. Mother Dairy, Kendriya Bhandar, and Super Bazaar were retail initiatives taken by governments.

2. Retail Conceptualization: In retail conceptualization phase, the pure-play retailers entered into the Indian retail market to grow the retail and to exploit the opportunities existing in the market. The majority of the retailers entered in the apparel segment.

3. Retail Expansion: In 2005-2010 phase of the Indian retail industry was the liveliest phase. In this phase, the new company entered into the market and new retail formats were developed. In this phase, retailers entered in food and general merchandise group.

4. Retail Consolidation and Growth: This phase is the recent phase of Indian retail. Retail industry moves towards small cities and rural areas. Large-scale entry of global brands. (www.ibef.com)

\subsection{Segmentation of Indian Retail Sector}

The Indian retail sector is classified into two segments. These segments are:

a) Unorganized Retail Sector

b) Organized Retail Sector

Originally, the retail industry in India was unorganized but, with the increase in the population, there is an alteration in taste and liking of the Indian consumers, the retail industry getting organized. The Indian retail sector 92 percent business is being run by 
unorganized retail sector.

\section{a) Indian Unorganized Retail Sector}

According to the National Accounts Statistics of India, the 'unorganized sector' includes units whose movement is not regulated by any statute or legal provision and/or those, which do not sustain regular accounts. According to a report by BCG (Boston Consulting Group), the unorganized retail sector contributed 92 percent in Indian retail sector. Unorganized retailing refers to the conventional formats of retailing, for example, the local Kirana shops, paan/beedi shops, convenience stores, hand cart, owner managed general stores etc.

\section{b) Indian Organized Retail Sector}

In India, organized retail sector cover up only a few share of the market potential. In India, between 2009-13, organized retail witnessed a CAGR (Compound Annual Growth Rate) of 19-20 percent. Organized Retail Penetration (ORP) in India is 8 percent, which is estimated very low as compared to the US 85 percent. This indicates retail in India has opportunities for expansion in this sector. Organized retail is expected to reach 24 percent by 2020 .

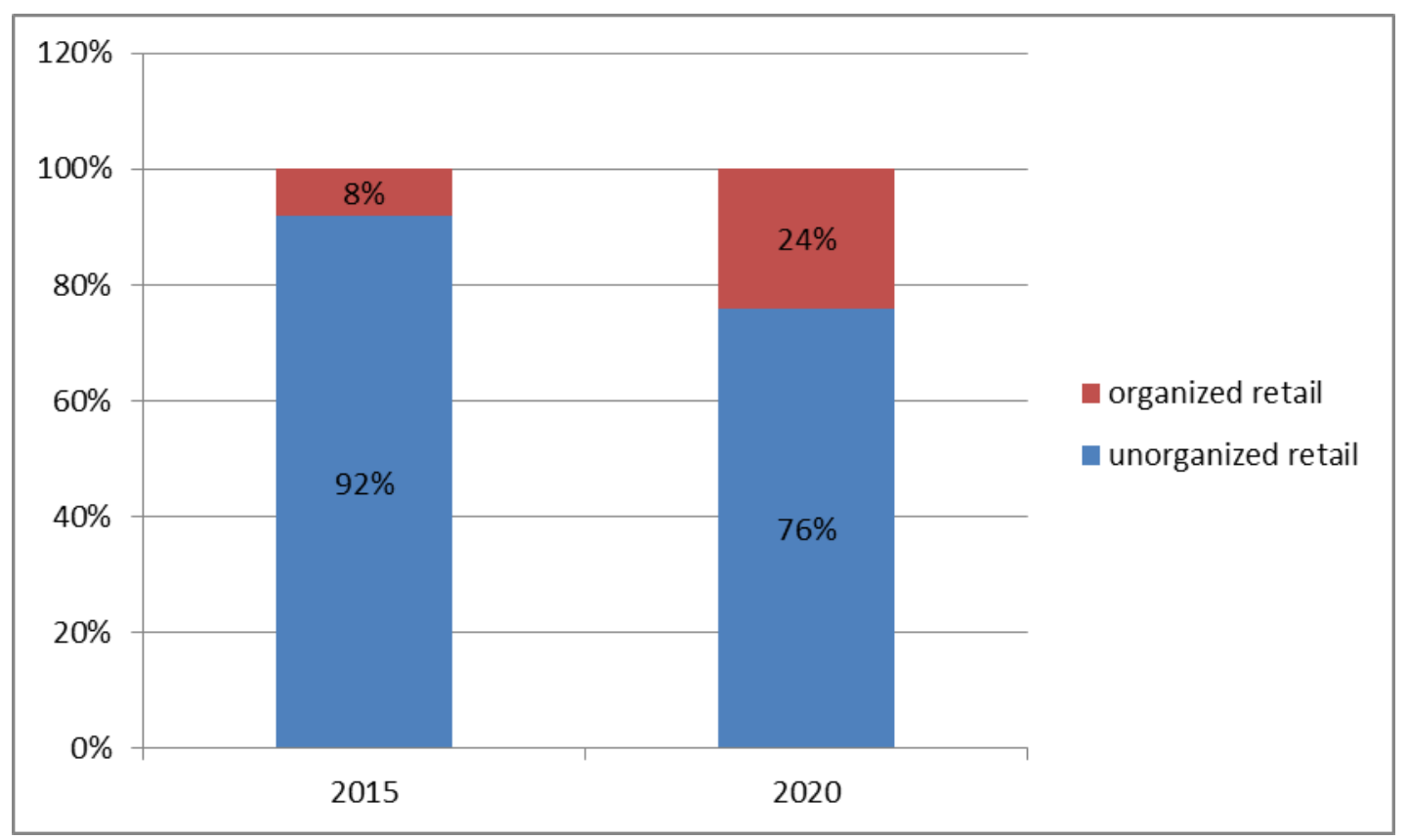

Figure 1. Growth Rate in Organized Retail

(Source: BCG, indiaretailing.com, Deloitte Report, TecSci Research)

This figure shows that organized retail increased 24 percent by 2020 from 8 percent in 2015 and unorganized retail fall down 76 percent by 2020 from 92 percent in 2015 .

Organized Retailing refers to trading deeds undertaken by certified retailers, which include the hypermarkets and retail chains and the privately owned big retail businesses. 
Table 1. Organized Retail Penetration And Key Trends Across Categories

\begin{tabular}{|c|c|c|c|c|}
\hline $\begin{array}{l}\text { Retail } \\
\text { category }\end{array}$ & $\begin{array}{l}\text { Category share as } \\
\text { a \% of total Mkt. } \\
(2014-15)\end{array}$ & $\begin{array}{l}\text { ORP }(\%) \\
\text { Organized } \\
\text { Retail } \\
\text { Penetration }\end{array}$ & $\begin{array}{l}\text { Approx. } \\
\text { Gross } \\
\text { Margin (\%) }\end{array}$ & Key trends \\
\hline $\begin{array}{l}\text { Food \& } \\
\text { Beverages }\end{array}$ & $69-70$ & $2-3$ & $3-14$ & $\begin{array}{l}\text { Large market and low ORP presents } \\
\text { robust opportunities }\end{array}$ \\
\hline $\begin{array}{l}\text { Clothing \& } \\
\text { Textile }\end{array}$ & $11-13$ & $17-20$ & $35-50$ & $\begin{array}{l}\text { High margins, increased preference } \\
\text { for branded apparel }\end{array}$ \\
\hline $\begin{array}{l}\text { Consumer } \\
\text { Durables }\end{array}$ & $4-5$ & $15-20$ & $10-20$ & $\begin{array}{l}\text { Wide range of price points and goods } \\
\text { after sales service are key } \\
\text { differentiators }\end{array}$ \\
\hline $\begin{array}{l}\text { Home decor \& } \\
\text { Furnishing }\end{array}$ & 3 & $5-6$ & $40-50$ & $\begin{array}{l}\text { Housing boom and increasing } \\
\text { aspiration levels are driving demand }\end{array}$ \\
\hline $\begin{array}{l}\text { Beauty, } \\
\text { Personal care }\end{array}$ & $8-11$ & $6-10$ & $20-40$ & $\begin{array}{l}\text { Growth driven by new product } \\
\text { launches, consumers' aspirations and } \\
\text { expansion plans of organized players }\end{array}$ \\
\hline Footwear & 2 & $16-17$ & $25-35$ & $\begin{array}{l}\text { Lifestyle brands are increasing their } \\
\text { product offerings and formats }\end{array}$ \\
\hline Others & $3-4$ & $9-30$ & $10-15$ & $\begin{array}{l}\text { Pharmacy retail, stationery retailers } \\
\text { etc. }\end{array}$ \\
\hline
\end{tabular}

(Source: Ministry of Statistics and Programme Implementation, a Report on 'Retail Reforms in India' by PWC, TechSci Research)

\subsection{Service Quality}

The concept of service quality is better known by understanding the concept of service and quality independently. For this purpose service quality is divided into two parts.

a) Service

b) Quality

Services are behavioral rather than physical entities and have been described as deeds, performances, and processes. The quality of a product or service is a customer's perception to 
which the product or service meets his or her expectations. Gronroos (1984) defined service quality as "the outcome of an evaluation process, where the customers compare their expectations with the services they have received." Parasuraman et al. (1988) defined service quality as a perceived judgment about an entity's overall excellence or superiority , posting service quality as an antecedent of perceived value and hence of outcomes such as a purchase.

\section{a) Services}

In simple terms, services are deeds, processes, and performances provided or coproduced by one entity or person for another entity or person. Broad definition is one that defines services to include "all economic activities whose output is not a physical product or construction, is a generally consumed at the time it is produced and provides added value in forms (such as convenience, amusement, timeliness, comfort, or health) that are essentially intangible concerns of its purchaser."

John Rathmell defined services in broad terms as "acts, deeds, performances, or efforts" and argued that they had different characteristics from goods - defined as "articles, devices, materials, objects, or things".

\section{b) Quality}

The International Organisation for Standardization (ISO) defines quality as the "totality of characteristics of an entity that bear on its ability to satisfy stated and implied needs."

Quality has been variously defined as:

Value (Abbott, 1955; Ferigenbaum, 1951)

Conformance to specifications (Gilmore, 1974; Levitt, 1972)

Conformance to requirements (Crosby, 1979)

Fitness for use (Juran, 1974, 1988)

Loss avoidance (Taguchi, cited in Ross, 1989)

Meeting and/or exceeding customers' expectations (Gronroos, 1993; Paraqsuraman, Zeithamal \& Berry, 1985)

The word quality means different things to different people according to the perspective.

David Garvin (1984) identifies five perspectives on quality.

1. The Transcendent View: As per the transcendent view quality is identical to excellence. It argues that people learn to identify quality only through the experience gained from repetitive exposure.

2. The Product Based Approach: Quality is precise and measurable. Differences in quality reflect differences in the quantity of an element or attribute possessed by the product. 
3. User-based Definitions: Quality lies in the eyes of the beholder. These definitions equate quality with maximum satisfaction. Different customers have different wants and needs.

4. The Manufacturing-based Approach: Quality is operations driven. It focuses on customers to internally developed specifications.

Value-based Definitions: Quality is a transaction between price and value. Quality defined as affordable excellence.

\subsection{Service Quality Dimensions}

In 1988, A. Parsuraman, Valarie Zeithaml and Leonard Berry have given five dimensions of service quality which are acceptable all over the world. These five dimensions are:

1. Reliability: the ability to perform the promised service dependably and accurately.

2. Responsiveness: willingness to help customers and provide prompt service.

3. Assurance: employees' knowledge and courtesy and their ability to inspire trust and confidence.

4. Empathy: caring, individualized attention given to customers.

5. Tangibles: the appearance of physical facilities, equipment, personnel and written materials.

\section{Review of Related Literature}

Parasuraman, Zeithamal \& Berry (1985) investigated the concept of service quality by the exploratory qualitative study. Focus group interviews with customers and in-depth interviews with executives were conducted in four services firms - retail banking, credit card, securities brokerage and product repair and maintenance to develop a theoretical model of service quality. Researchers found that despite the type of services, consumers used related criteria in the assessment of service quality. These criteria come under ten service quality dimensions reliability, responsiveness, competence, access, courtesy, communication, credibility, security, understanding/ knowing the customer and tangibility.

Caruana, Money \& Berthon (2000) conducted an exploratory research on customers of an audit firm with the help of questionnaire to know that whether value plays the moderating role between service quality and satisfaction. The hypothesis of the study proved the direct relation between service quality and satisfaction and a moderating effect of value on satisfaction. The coefficient alpha showed negative moderating effect. Regression analysis proved the moderating role of value.

Sureshchandar, Rajendran \& Anantharaman (2002) conducted research for analyzing the relationship between service quality and customer satisfaction with a different approach by collected data from 277 customers of 43 different banks in India. The outcome indicated by t-test showed that service quality and customer satisfaction were two different constructs. The high correlation found the high relationship between service quality and customer satisfaction 
with respect to the five factors. This was also supported by cross-tabulation analysis. In this study, customer satisfaction was operationalized along with the identical factors as service quality to know the customer satisfaction as a multidimensional construct like service quality.

Sachdev\&Verma(2002) revealed that customers should expectations and would expectations differ considerably. Factor analysis indicated that would expectations were nearer to real performance. The study indicated that all the service quality dimensions were significant in banking and fast food services. The study found that the five -factor structure proposed by Parasuraman, Zeithaml \& Berry for service quality was not accepted.

Dedeke (2003) evaluated service quality as a fulfilment-oriented construct rather than as a discrepant construct. In this study, research purposed a difference-based construct for evaluating the perception of the customer with respect to a service provider. Researcher construct service quality grid for avoiding the limitations of SERVQUAL. By the examination of secondary research on SERVQUAL, researcher recommended that the tool, based on its item pool, better fits service firms with dominant customer-staff interactions.

Blose \& Tankersley (2004) introduced an innovative application of Data Envelopment Analysis (DEA) helpful for the diagnosis and management of service quality. The study was conducted in US retail electronic energy market. The DEA provides an analytical relation between service quality dimensions and final goals of retail service providers and service consumers. DEA technique provided an imaginary target model for an ideal combination of performance levels for the different service quality dimensions.

Jain \& Gupta (2004) assessed the diagnostic power of two service quality scales: SERVQUAL vs. SERVPREF in fast food restaurants in Delhi. The study found that in terms of diagnostic power SERVQUAL scale was more suitable but SERVPREF scale provided more convergent and discriminant validity in explaining of service quality construct.

Olorunniwo, Hsu \& Udo (2006) studied the service quality, customer satisfaction and behavioural intentions in the service factory in a large metropolitan area of the USA. They found that service quality factors, responsiveness and knowledge dimensions more significant than the tangible and recovery dimensions. The result indicated that service quality indirect effect on behavioural intentions through customer satisfaction was stronger than a direct effect of service quality on behavioural intentions in the context of the service factory.

Parikh (2006) measured the retail service quality of retail stores in India by RSQS (Retail Service Quality Scale) developed by Dabholkar, Thorpe and Rentz's in 1996. They found that the scale reliable to measure service quality. Analyzed by the factor analysis the gaps between perceptions and expectations did not match the five factors of service quality. They exposed the need for improvements in the retail service quality in all aspects for the applicability of RSQS scale in Indian retail stores.

Kaul (2007) examined the Retail Service Quality Scale (RSQS) applicability in Indian specialty apparel stores in Bangalore city. The researcher found that the retail service quality scale five dimensions - physical aspects, reliability, personal interaction, problem-solving and policy were not suitable for measuring service quality in India. But the scale is fairly 
reliable and valid in measuring a single construct.

Khan, Mahapatra \& Sreekumar (2007) evaluated the service quality in technical institutes in India by using DEA ( Data Envelopment Analysis ) approach .In this study, DEA approach was used to obtain the efficiency of DMUs ( Decision Making Units ) by using CRS( Constant Return to Scale ) and VRS ( Variable Return to Scale ) model. Researchers found the difference between the conventional and DEA ranking methods.

Landrum et al. (2009) measured the service quality performance of an electronic library information system in U.S. by SERVQUAL scale. They found that among five dimensions -tangibility, reliability, responsiveness, assurance \& empathy, two dimensions -reliability and responsiveness found more significant in users perceptions.

Khare et al. (2010) conducted exploratory research on retailer behaviour in determining service quality in Indian retail sector. The study was conducted in Northern India on grocery and household products retailers. Researchers used traditional SERVQUAL scale and found that high positive correlation existed between different service quality dimensions. By using ANOVA test they found all the age groups had similar perceptions about the service quality attributes in retailing.

Yuen \& Chan (2010) examined the effect of retail service quality and product quality on customer loyalty on two levels (store and staff) of retail relationships in Window Fashion Gallery, Hunter Douglas in curtain retail sector. They found that only three dimensions physical aspects, reliability, and problem-solving were significant to customer loyalty to store and only personal interaction dimension was positively associated with customer loyalty to staff. Post hoc analysis results showed that reliability, physical aspects, problem-solving and aesthetics dimensions had significant impacts on customer loyalty to store under the gender effect.

Zehir et al. (2011) investigated the effect of brand communication and service quality in building brand loyalty through brand trust in the automobile industry in Turkey. The empirical research was based on the development and administration of a self-administered survey. They found that by using different statistical tools like correlation, regression and factor analysis, the perceptions of brand communications and service/product quality viewed a antecedents to brand trust and affect brand loyalty.

Singh, Ajmer (2012) found that service quality is having a significant impact on the customer loyalty in retail outlets. Hence service quality is an important factor for improving upon the business performance.

Singh, Ajmer (2013) found a significant impact of service quality on the customer satisfaction in retail outlets. So it becomes important to provide the good service quality for achieving the high customer satisfaction level.

Mathur, Sharma \& Jain (2013) examined the applicability of Retail Service Quality Model (RSQS) in organized retail stores of Udaipur city. They found that all the five dimensionsphysical aspects, reliability, personal interaction, problem-solving and policy of RSQS suited 


\section{Macrothink}

for measuring retail service quality, particularly in clothing stores $\&$ food stores.

Sathiyabama \& William (2015) examined the retailers' service quality in selected retail outlets in Coimbatore city with a sample size of 384 respondents. They found that there was a relationship between responsiveness, attractiveness, assurance and reliable service. The study indicated that reliable service, price, and assurance more important factor which influences retailers service.

\section{Service Quality Models}

1. Nordic School

- Gronroos model $(1978 ; 1982 ; 1984)$

- Lehtinen and Lehtinen three-dimensional model (1991)

2. North American School

- Parasuraman, Zeithaml and Berry Gap model $(1985,1988,1990)$

3. The Three- component Model (1994)

4. Retail Service Quality Scale model (1996)

5. Brady and Cronin Hierarchical model (2001)

\subsection{Nordic School}

Christain Gronroos is the key contributor to the Nordic school of the service quality. In 1984, Gronroos developed a model, which is a form of gap analysis to explain what he calls the 'missing service quality concept.' The model focuses primarily on the construct of an image which represents the point at which a gap may occur between expected service and perceived service. According to Gronroos (1984), perceived quality means that expected service and perceived service of a firm has the match to each other. Gronroos distinguishes between technical quality and functional quality as the components of the service image delivery.

Gronroos service quality model consists of three dimensions:

a) Technical Quality

b) Functional Quality

c) Image

a) Technical Quality: Technical quality refers to what the customer is truly getting from the service. This is capable of objective measurement, as with tangible goods.

b) Functional Quality: Functional quality refers to how the technical elements of service are receiving by the customers. This is can't be measurable objectively like technical quality.

The functional quality is professed in a subjective manner. 


\section{Macrothink}

Business and Economic Research

ISSN 2162-4860 2016, Vol. 6, No. 1

c) Image: Consumers expectations are influenced by the company's image. The corporate image of a firm is the end result of how customers perceived the firm. The corporate image can be built up by the technical and functional quality of the firm services.

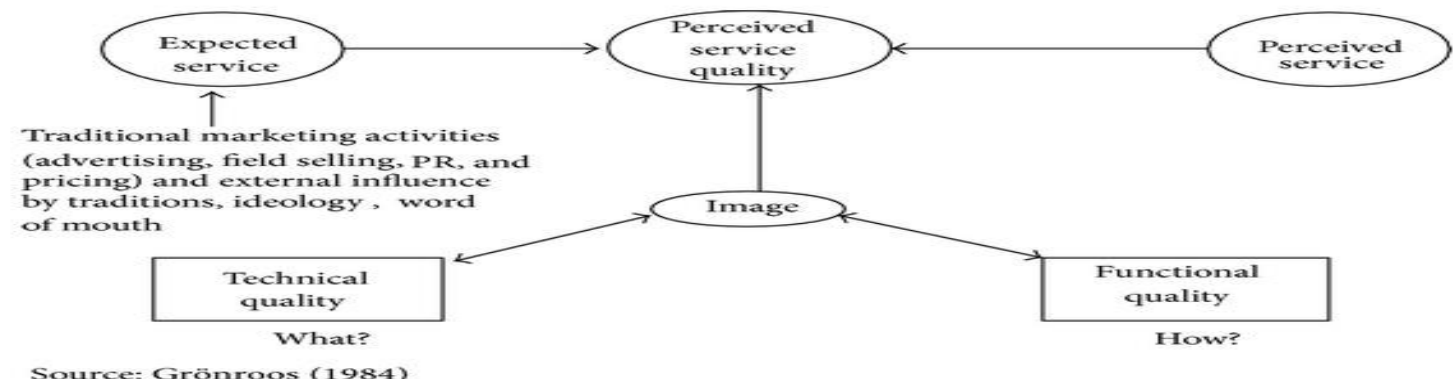

- Lehtinen and Lehtinen Three-Dimensional Model (1991)

Uolevi Lehtinen and Jarmo R. Lehtinen (1992) developed another service quality model which is also having three dimensions of service quality. The three dimensions model of service quality by Lehtinen \& Lehtinen (1991) :

1. Physical Quality

2. Interactive Quality

3. Corporate Quality

Physical quality linked to the tangible aspects of the service. Interactive quality involves the interactive nature of services and refers to the two-way flow that occurs between the customer and the service provider. Corporate quality refers to the image attributed to a service provider by its present and potential customers as well as other public. Corporate quality is generally more stable in nature than physical quality and interactive quality.

\subsection{North American School}

The North American school models were more popular than the Nordic school models and the main contributor to the North American school was Parasuraman, Zeithaml \& Berry gap model (1988). The American school model which also called as disconfirmation model had been originally developed in 1985 and refined in 1985, 1991, 1993 and 1994 (Parasuraman et al 1988, 1991, 1993, 1994). According to Gap Model, the service quality is a function of performance and expectations.

The formula is given below:

$$
\begin{gathered}
\mathrm{SQ}=\sum_{f=1}^{k}\left(P_{i j}-E i j\right) \\
\mathrm{SQ}=\text { overall service quality } \\
\mathrm{k}=\text { number of attributes } \\
\mathrm{P}_{\mathrm{ij}}=\text { performance perception }
\end{gathered}
$$


$\mathrm{E}_{\mathrm{ij}=}$ service quality expectation

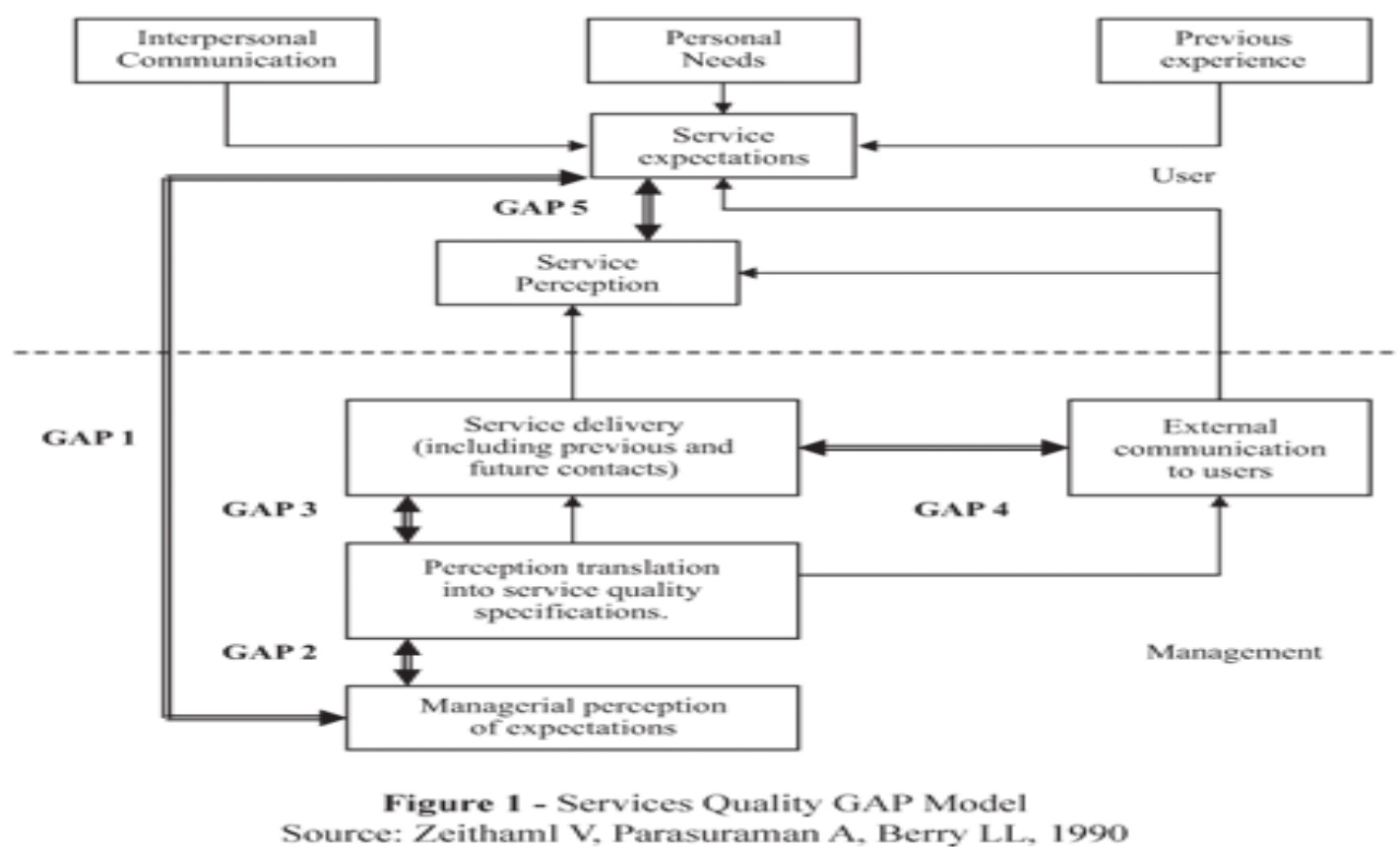

Gap 1: difference between consumer expectations and management perceptions of consumer expectations. This gap is known as the listening gap.

Gap 2: difference between management perceptions of consumer expectations and service quality specifications. It is known as the service design and standards gap.

Gap 3: difference between service quality specifications and the service actually delivered is known as the service performance gap.

Gap 4: difference between service delivery and what is communicated to the service to the consumer. This gap is known as the communication gap.

Gap 5: difference between consumer expectations and perceptions is known as the customer gap.

The gap model of service quality serves as an outline for service firms to improve service quality, service delivery, and services marketing.

\subsection{The Three-Component Model: developed by Rust \& Oliver in 1994.}

Rust and Oliver (1994) extended the Nordic model. They emphasized that the service environment is an essential dimension of service quality. 


\section{The three-component model Rust \& oliver (1994)}

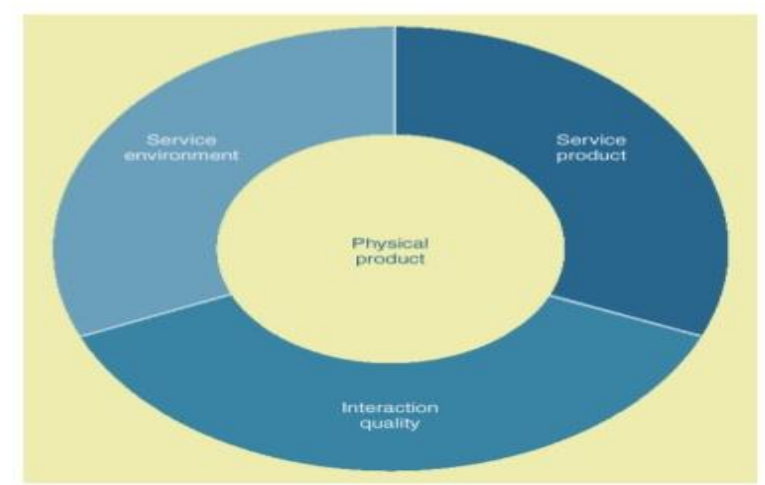

Service environment viewed as the internal environment. It is focused on organizational culture and external environment which primarily looks at the physical ambiance of the service setting. They also brought the physical product into the service setting. Based on these dimensions we can measure the service quality.

\subsection{Retail Service Quality Scale Model (1996)}

Retail Service Quality Scale was developed by Dabholkar, Thorpe, and Rentz in 1996 for measuring service quality in the retail sector. RSQS has a five-dimensional structure of which three dimensions include two sub- dimensions each.

The five dimensions of RSQS are:

1. Physical Aspects

2. Reliability

3. Personal Interaction

4. Problem Solving

5. Policy

Proposed Hierarchical Structure for Retail Service Quality

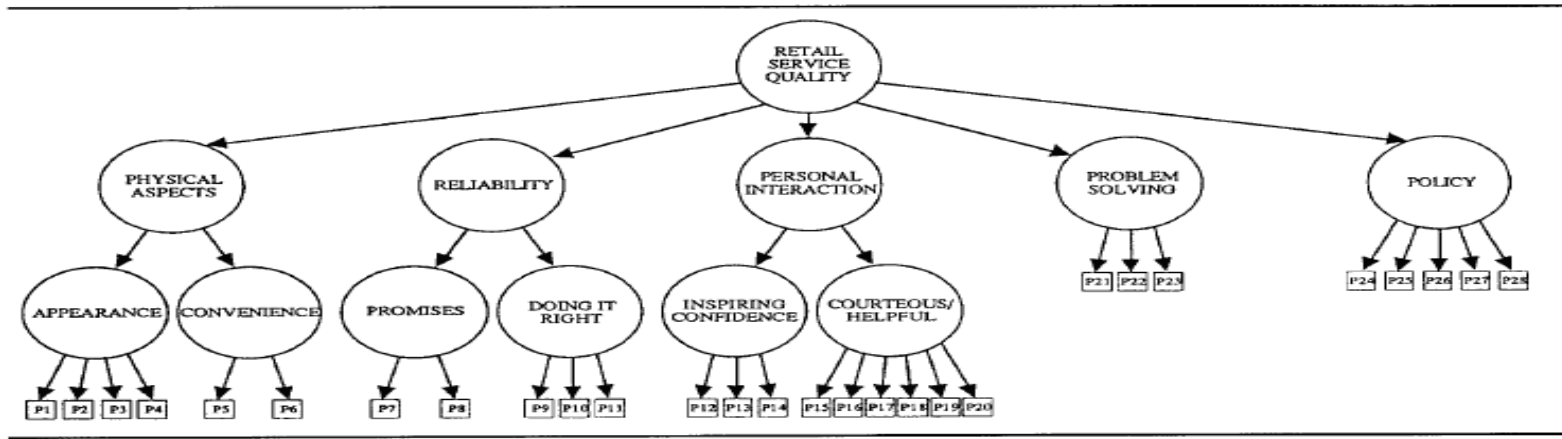

Source: Dabholkar, Thorpe \& Rentz (1996) 


\begin{tabular}{|l|l|}
\hline Dimensions & Sub-Dimensions \\
\hline 1. Physical Aspect & $\begin{array}{l}\text { a) Retail store appearance } \\
\text { b) Store layout }\end{array}$ \\
\hline 2. Reliability & $\begin{array}{l}\text { a) Keep their promises } \\
\text { b) Do the right things }\end{array}$ \\
\hline 3. Personal Interaction & $\begin{array}{l}\text { a) Retail store personnel is courteous, helpful } \\
\text { 4. Problem Solving }\end{array}$ \\
\hline b) Inspire confidence in customers
\end{tabular}

3.4 Hierarchical Model: developed by Brady \& Cronin in 2001.

The hierarchical model by Brady \& Cronin (2001) integrates the conceptualization of service quality by suggesting a service quality model with three dimensions. The three dimensions are as below.

a) Interaction Quality

b) Physical Environment Quality

c) Outcome Quality

Each of these dimensions consists of three sub-dimensions and the collective evaluation of the sub-dimensions forms the perception of that dimension. The collective perception of these dimensions leads to the overall service quality perception.

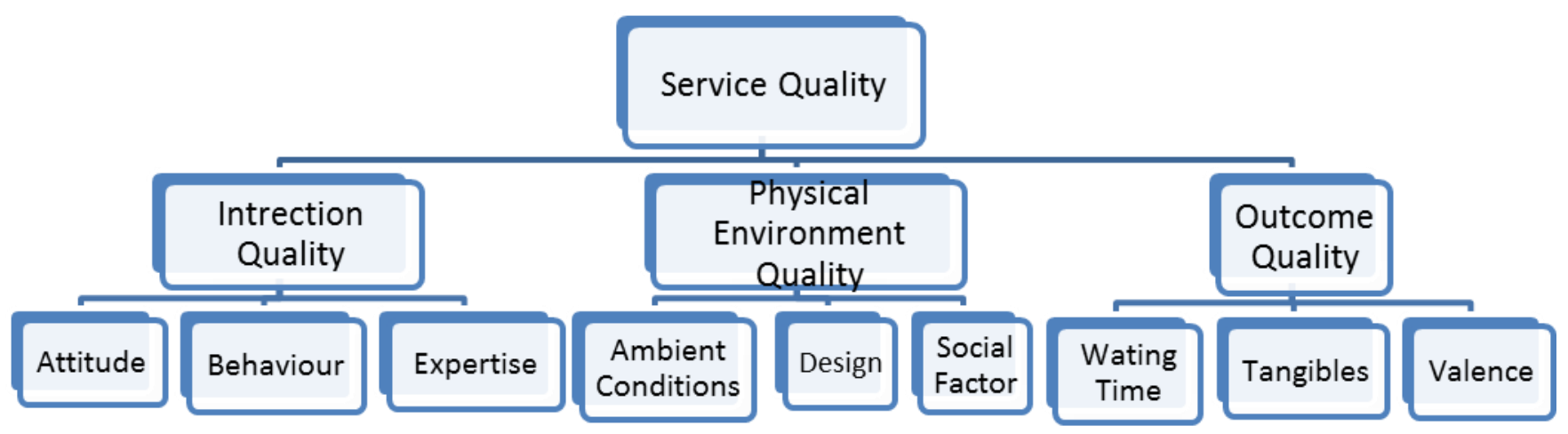

Source: Brady and Cronin, $(2001, p .37)$ 
Table 2. Critical Analysis of Different Service Quality Models

\begin{tabular}{|l|c|l|l|}
\hline Authors & Year & Model & Dimensions \\
\hline Christain Gronroos & 1984 & Gronroos Model & $\begin{array}{l}\text { Technical quality, Functional quality, } \\
\text { Image }\end{array}$ \\
\hline $\begin{array}{l}\text { A.Parasuraman,Valarie Zeithaml } \\
\text { \& Leonard Berry }\end{array}$ & 1988 & Gap Model & $\begin{array}{l}\text { Reliability, Responsiveness, } \\
\text { Assurasnce,Empathy,Tangibility }\end{array}$ \\
\hline $\begin{array}{l}\text { Uolevi Lehtinen \& Jarmo R. } \\
\text { Lehtinen }\end{array}$ & 1991 & $\begin{array}{l}\text { Three Dimensional } \\
\text { Model }\end{array}$ & $\begin{array}{l}\text { Physical quality, Interactive quality, } \\
\text { Corporate quality }\end{array}$ \\
\hline Rust \& Oliver & 1994 & $\begin{array}{l}\text { Three-component } \\
\text { Model }\end{array}$ & $\begin{array}{l}\text { Service environment, } \\
\text { Interaction quality, } \\
\text { Service product }\end{array}$ \\
\hline Dabholkar,Thorpe \& Rentz & 1996 & RSQS Model & $\begin{array}{l}\text { Physical aspects, } \\
\text { Reliability, Personal interaction, Problem } \\
\text { solving, Policy }\end{array}$ \\
\hline Brady \& Cronin & 2001 & Hierarchical Model & $\begin{array}{l}\text { Interaction quality, } \\
\text { Physical environment quality, Outcome } \\
\text { quality }\end{array}$ \\
\hline
\end{tabular}

\section{Conclusion}

In this paper service quality models are analyzed on the basis of literature review as well by critically examining the different models in service quality as suggested by different authors. The Nordic school which is also known as European school focused on primarily technical quality and image and it describes service quality by using overall categorical terms. On the other hand, North American school mainly focused on functional quality and it defines service quality by using descriptive terms. In Gronroos model perceived quality is based on the expected service and perceived service of a firm .PZB gap model defines service quality as a function of performance and expectations on the basis of five dimensions. The three component model is based on the Nordic model; it includes an important dimension service environment. RSQS model is based on five dimensions like gap model. The review of different service quality models shows that most of the service quality models evaluate service quality by comparing the service quality perception with the service quality expectation. It is clear from the review of the service quality models that none of the service quality model is suitable in all situations and therefore, it gives the opportunities to the researcher for the further research in this area. We find out that service quality is more important for customers' satisfaction.

\section{References}

Parasuraman, A., Zeithaml, Valarie A., \& Berry, Leonard L. (1985).A Conceptual Model of Service Quality and Its Implication for Future Research. Journal of Marketing, 49, 41-50. http://dx.doi.org/10.2307/1251430

Caruana, Albert, Money, Arthur H., \& Berthon, Pierre R. (2000).Service Quality and Satisfaction-the Moderating Role of Value. European Journal of Marketing, 
34(11/12), .1338-1352.http://dx.doi.org/10.1108/03090560010764432

Sachdev,Sheetal B., \& Verma, Harsh V. (2002).Customer Expectations and Service Quality Dimensions Consistency-A Study of Select Industries. Journal of Management Research, 2(1), 43-52.

Sureshchander, G. S., Rajenderan, Chandrasekharan \& Anantharaman, R. N. (2002). The Relationship between Service Quality and Customer Satisfaction- A Factor Specific Approach. $\begin{array}{lllll}\text { Journal of } & \text { Services } & \text { Marketing, } & \text { 16(4), }\end{array}$ http://dx.doi.org/10.1108/08876040210433248

Dedeke, Adenekan. (2003). Service Quality: A Fulfilment- Oriented and Interaction-Centered Approach. Managing Service Quality, 13(4), 276-289. http://dx.doi.org/10.1108/09604520310484699

Jain,Sanjay K., \& Gupta, Garima. (2004). Measuring Service Quality: SERVQUAL vs. SERVPREF Scales. Vikalpa, 29(2), 25-37. Retrieved from http://search.ebscohost.com/login.aspx ?direct=true \&db=bth\&AN=14024712\&site=ehost-live

Blose, Julia E., \& Tankersley, William B.(2004).Linking Dimensions of Service Quality to Organizational Outcomes. Managing Services Quality, 14(1), 75-89. http://dx.doi.org/10.1108/09604520410513686

Olorunniwo,Festus, Hsu, Maxwell K., \& Udo, Godwin J.(2006).Service Quality, Customer Satisfaction and Behavioral Intentions in the Service Factory. Journal of Services Marketing, 20(1), 59-72. http://dx.doi.org/10.1108/08876040610646581

Parikh, Darshan. (2006).Measuring Retail Service Quality: An Empirical Assessment of the Instrument. Vikalpa, 31(2), 45-55. Retrieved from http://www.vikalpa.com/pdf/articles/2006/2006_apr_jun_45_56.pdflnhttp://content.ebscohost .com/ContentServer.asp?T=P\&P=AN\&K=21559049\&EbscoContent=dGJyMNLe80SeqLI40 dvuOLCmrlGeprRSr624TLGWxWXS\&ContentCustomer=dGJyMPGutky3rbRIuePfgeyx44 Dt6fIA\&D=buh

Kaul,Subhasini. (2007). Measuring Retail Service Quality: Examining Applicability of International Research Perspectives in India. Vikalpa, 32(1), 15-26.

Landuram et al. (2009). Measuring is System Service Quality with SERVQUAL:Users' Perception of Relative Importance of the Five SERVPREF Dimensions. Informing Science: The International Journal of an Emerging Transdiscipline, 12, 17-35. http://doi.org/10.1145/2038056.2038060

Yuen, Euphemia F. T., \& Chan, Sian S. L. (2010). The Effect of Retail Service Quality and Product Quality on Customer Loyalty. Database Marketing \& Customer Strategy Management, 17(3/4), 222-240.http://dx.doi.org/10.1057/dbm.2010.13

Khare, Arpita, Parveen, Ceeba. \& Rai, Reena(2010).Retailer Behavior as Determinants of Service Quality in Indian Retailing. Journal of Retail \& Leisure Property, 9(4), 303-317. http://dx.doi.org/10.1057/rlp.2010.14 
Zehir et al. (2011).The Effect of Brand Communication and Service Quality in Building Brand Loyalty through Brand Trust; The Empirical Research on Global Brands. Procedia Social \& Behavior Sciences, 24, 1218-1231.http://dx.doi.org/10.1016/j.sbspro.2011.09.142

Mathur, Dipin, Sharma, Manoj Kumar \& Jain, Apeksha. (2013). Assessment of Service Quality in Organized Retail Store of Udaipur. IOSR Journal of Business and Management, 11(3), 57-60. http://dx.doi.org/10.9790/487X-1345759

Singh, Ajmer. (2012). Impact of Perceived Service Quality on Customer Loyalty Intension in Retail Outlets. Europan Journal of Business Management, 4(21), 138-149. http://www.iiste.org/Journals/index.php/EJBM/article/viewFile/3625/3674

Singh, Ajmer (2013). Relationship between Service Quality and Customer Satisfaction in Organized Retail Outlets. Developing Country Studies, 3(1), 84-95. https://papers.ssrn.com/sol3/Data_Integrity_Notice.cfm?abid=2246368

Sathiyabama, R., \& William, A. John. (2015). A Study on Retailers Service Quality in Selected Retail Outlets in Coimbatore City. International Journal of Recent Scientific Research, 6(7), 5333-5338.

Reeves, Carol A., \& Bednar, David A. (1994). Defining Quality:Alternatives and Implications. The Academy of Management Review, 19(3), 419-445. http://dx.doi.org/10.2307/258934

Dabholkar, Thorpe and Rentz (1996).A Measure of Service Quality for Retail Stores:Scale Development and Validation. Journal of the Academy of Marketing Science, 24(1), 3-16. http://dx.doi.org/10.1007/BF02893933

Bateson,John E. G. (1995). Managing Service Marketing (3rd ed.).Fort Worth, Texas: The Dryden Press 1995, 558-565.

\section{Bibliography}

Lovelock, Christopher,Wirtz,Jochen \& Chatterjee,Jayanta(2010).Service Marketing-Pepole,Technology,Strategy(6th ed.).Noida: Dorling Kindersley (India) Pvt.Ltd.

Zeithaml,Valarie A., Bitner, Mary Jo,Gremler,Dwayne D. \& Pandit, Ajay (2011).Services Marketing-Integrating Customer Focus Across the Firm (5th ed.).New Delhi: Tata McGraw Hill Education Private Limited.

\section{Reports}

Media Reports, Press Releases, DIPP Publication, Press Information Bureau, India Budget 2015-16.

AT Kearney 2015

Technopak Advisors Pvt. Ltd, BCG, TechSci Research

Deloitte Report

Ministry of Statistics and Programme Implementation a Report on ' Retail Reforms in India' 
by PWC, TechSci Research

Websites

www.indiaretailing.com,

www.ibef.com

\section{Copyright Disclaimer}

Copyright for this article is retained by the author(s), with first publication rights granted to the journal.

This is an open-access article distributed under the terms and conditions of the Creative Commons Attribution license (http://creativecommons.org/licenses/by/3.0/). 